\title{
DNA-based diversity assessment reveals a new coral barnacle, Cantellius alveoporae sp. nov. (Balanomorpha: Pyrgomatidae) exclusively associated with the high latitude coral Alveopora japonica in the waters of southern Korea
}

\author{
Hyun Kyong Kim ${ }^{1,2}$, Benny K.K. Chan ${ }^{\text {Corresp., }}{ }^{3}$, Sung Joon Song ${ }^{1}$, Jong Seong Khim ${ }^{\text {Corresp. } 1}$ \\ ${ }^{1}$ School of Earth and Environmental Sciences \& Research Institute of Oceanography, Seoul National University, Seoul, Republic of Korea \\ 2 Animal Research Division, Honam National Institute of Biological Resources, Jeollanam-do, Republic of Korea \\ 3 Biodiversity Research Center, Academia Sinica, Taipei, Taiwan \\ Corresponding Authors: Benny K.K. Chan, Jong Seong Khim \\ Email address: chankk@gate.sinica.edu.tw, jskocean@snu.ac.kr
}

In the present study, the Indo-Pacific coral associated barnacle Cantellius euspinulosum (Broch, 1931) was found to have cryptic species in Korea, Taiwan and other regions based on molecular studies. However, the original specimens of $C$. euspinulosum from Broch have not been previously described or illustrated, making it difficult to assign which cryptic species to the original $C$. euspinulosum. The original specimen of $C$. euspinulosum was examined and illustrated here, and the species identity of $C$. cf. euspinulosum collected from Jejudo Island in the present study and other cryptic species (based on literature illustrations) in the Indo-Pacific were evaluated. C. euspinulosum from Singapore, Java, Mergui Archipelago in Andaman Sea and Nha Trang represented the $C$. euspinulosum identified by Broch (1931). It is a generalist on Acropora, Favia, Favites, Leptoria, Montipora, Pchyseris and Pocillipora corals and distributed in the Indo-Pacific region. Morphological examination and DNA sequencing (COI, 12S DNA sequences) in the present study showed that $C$. cf. euspinulosum from Jejudo Island, Korea represents a distinct species, herein named $C$. alveoporae sp. nov. Cantellius alveroporae sp. nov. is a specialist species that only grows on Alveopora and also present in Palau, and Ogasawara Island in Japan. Cantellius cf. euspinuloum in Taiwan, the Moscos Island, and Australia belong to several other distinct species awaiting further morphological and molecular studies. At least five cryptic species of $C$. euspinulosum were identified in the present study, including both specialist and generalists. 


\section{DNA-based diversity assessment reveals a new coral barnacle,}

\section{Cantellius alveoporae sp. nov. (Balanomorpha: Pyrgomatidae)}

3 exclusively associated with the high latitude coral Alveopora japonica

\section{4 in the waters of southern Korea}

6 Short Title: Cryptic diversity of coral barnacles

Hyun Kyong Kim ${ }^{1,2}$, Benny K.K. Chan ${ }^{3, *}$, Sung Joon Song ${ }^{1}$, Jong Seong Khim ${ }^{1, *}$

${ }^{1}$ School of Earth and Environmental Sciences \& Research Institute of Oceanography, Seoul

11 National University, Seoul 08826, Republic of Korea

${ }^{2}$ Animal Research Division, Honam National Institute of Biological Resources, Jeollanam-do

1358762 , Republic of Korea

$14{ }^{3}$ Biodiversity Research Center, Academia Sinica, Taipei 115, Taiwan

17 Corresponding Authors:

18 Benny K.K. Chan

19 Biodiversity Research Center, Academia Sinica, Taipei 115, Taiwan

20 Email address: chankk@gate.sinica.edu.tw

21

22 Jong Seong Khim 
23 School of Earth and Environmental Sciences \& Research Institute of Oceanography, Seoul

24 National University, Seoul 08826, Republic of Korea

25 Email address: jskocean@snu.ac.kr 


\section{Abstract}

27 In the present study, the Indo-Pacific coral associated barnacle Cantellius euspinulosum (Broch, 28 1931) was found to have cryptic species in Korea, Taiwan and other regions based on molecular studies. However, the original specimens of C. euspinulosum from Broch have not been previously described or illustrated, making it difficult to assign which cryptic species to the original $C$. euspinulosum. The original specimen of C. euspinulosum was examined and illustrated here, and the species identity of $C$. cf. euspinulosum collected from Jejudo Island in the present study and other cryptic species (based on literature illustrations) in the Indo-Pacific were evaluated. $C$. euspinulosum from Singapore, Java, Mergui Archipelago in Andaman Sea and Nha Trang represented the C. euspinulosum identified by Broch (1931). It is a generalist on Acropora, Favia, Favites, Leptoria, Montipora, Pchyseris and Pocillipora corals and distributed in the Indo-Pacific region. Morphological examination and DNA sequencing (COI, 12S DNA sequences) in the present study showed that $C$. cf. euspinulosum from Jejudo Island, Korea represents a distinct species, herein named C. alveoporae sp. nov. Cantellius alveroporae sp. nov. is a specialist species that only grows on Alveopora and also present in Palau, and Ogasawara Island in Japan. Cantellius cf. euspinuloum in Taiwan, the Moscos Island, and Australia belong to several other distinct species awaiting further morphological and molecular studies. At least five cryptic species of $C$. euspinulosum were identified in the present study, including both specialist and generalists.

Keywords DNA barcoding, new coral barnacle, cryptic species, Indo-Pacific region, biodiversity management 
49 habitats show the highest diversity in the marine environment, with most fauna exhibiting 50 symbiosis with corals (Roberts et al., 2002; Stella et al., 2011; Dreyer \& Chan, 2020). Several 51 studies on coral symbiotic fauna have been conducted, including trapezoids and gall crabs, 52 polychaetes, bivalves, and barnacles (Goldberg, 2013). Coral hosts play significant ecological 53 roles by providing habitat, food, refuge, and mating sites for coral-associated invertebrates (Stella 54 etal., 2011).

55 Barnacles (Cirripedia) are ubiquitous across marine environments (Chan \& Høeg, 2015).

56 Several groups of barnacles are associated with fire and scleractinian corals (Anderson, 1992; 57 Tsang et al., 2009; Malay \& Michonneau, 2014). These barnacle groups have different lifestyles 58 (burrowing or epibiotic on corals), with molecular phylogeny delineating them as paraphyletic 59 (Malay \& Michonneau, 2014; Tsang et al., 2014). The family Pyrgomatidae exclusively grows 60 inside scleractinian corals (Hiro, 1935). The body cavity of pyrgomatid barnacles is embedded 61 inside the coral skeleton, with a cylindrical base, and the shell is flattened (Hiro, 1935; Chan et 62 al., 2020). Coral-associated barnacles include generalists, which live in a wide range of corals, and 63 specialists, which only live in specific coral host species (Ogawa \& Matsuzkai, 1992; Chan et al., 64 2020). Such host-specificity is correlated to their phylogenetic level (Tsang et al., 2014).

65 Previous biodiversity assessments of coral barnacles and their host-specificity were largely 66 based on morphological approaches. These approaches resulted in many species (for example, 67 Cantellius pallidus) being considered as generalists, showing very wide geographical distributions. 68 Traditional morphological approaches faced challenges due to the great morphological variation 69 exhibited by barnacles among hosts; consequently, conclusions cannot be made due to this high 70 phenotypic plasticity (Ross \& Newman, 1973; Anderson, 1992). With the development of 71 molecular approaches in taxonomic and phylogenetic studies of crustaceans, the diversity of 
72 barnacles growing on corals has included some cryptic species. Furthermore, host ranges were 73 found to be narrower when compared to the results deducted from morphological approaches 74 (Kolbasov et al., 2015; Kolbasov et al., 2016). Thus, molecular approaches open up new insights 75 on the host-usage and geographical distribution of coral barnacles.

76 A review by Chan et al. (2020) showed that the diversity of coral barnacles in the west Pacific 77 region is positively associated with coral host diversity. The waters around Okinawa Island support 78 the greatest coral diversity in the Pacific (350 species identified to date), including 20 species of coral barnacles. In contrast, only 20 coral species were recorded in the higher latitude coral community in the Japan Sea region, including four coral barnacle species (Asami \& Yamauchi, 1997; Chan et al., 2020). Coral communities occurring at high latitudes are termed as marginal communities, as they are at the marginal distribution of coral triangles. Marginal coral communities are characterized by low diversity, slow growth rates, and high susceptibility to 84 global climatic changes (Chan et al., 2018).

Jejudo Island in the waters of Korea is at the northern-most limit of the coral distribution in the West Pacific. In the region, only nine Scleractinian coral species have been recorded to date. These corals include the high latitude coral Alveopora japonica, which is a common foundation species, with its spatial distribution (and hence abundance) recently expanding due to global climate change. Chan et al. (2018) studied the molecular diversity of coral barnacles in the waters around the Jejudo Island, and recorded three coral barnacle species growing on four Scleractinian coral

91 hosts. The barnacle Cantellius arcuatus was only found on the coral Montipora millipora.

92 However, the DNA sequences of C. arcuatus are similar to those of samples collected in Japan, 93 Taiwan, Malaysia, and Papua New Guinea growing on a variety of hosts. Thus, C. arcuatus is 94 likely a generalist species, with a wide distribution range. It only inhabits a single species of coral 
95 in the marginal community, probably due to the lower availability of other coral host species.

96 Another barnacle, Pyrgomina oulastreae (Utinomi, 1962), was found on Psammocora and

97 Oulastrea corals in the waters of Korea and Japan, suggesting it is a generalist. A third species

98 Cantellius cf. euspinulosum was only found on Alveopora japonica. The DNA sequences of this

99 barnacle species did not match any available GenBank sequences, questioning it could be a new

100 species. However, the morphology of this species is similar to that of Cantellius euspinulosm.

101 Cantellius euspinulosum is an Indo-Pacific coral barnacle that invades many coral hosts (Ross

$102 \&$ Newman, 1973). However, the species identity of C. euspinulosum remains unclear because

103 illustrations from different reports of this species show large variations in morphological

104 description. Cantellius euspninulosa was originally named Creusia spinulosa forma euspinulosa

105 by Broch (1931). Broch stated that this forma euspinulosa represented Darwin's C. spinulosa

106 variety 1 (Darwin, 1854). Unfortunately, however, Broch (1931) did not provide any illustrations

107 of collected forma euspinulosa specimens. Ross \& Newman (1973) established the genus

108 Cantellius, and considered C. spinulosa forma euspinulosa as C. euspinulosum. At present, all

109 identifications of C. euspinulosum have been based on the drawings of opercular plates in Darwin

110 (1854). Without any clear examination of the C. euspinulosum from Broch's specimens, it would

111 be difficult to ascertain whether they represent cryptic species.

112 The present study re-examined and illustrated the type specimen of C. euspinulosum from the

113 Zoological Museum at the University of Copenhagen, and evaluated species identity and host-

114 usage of $C$. cf. euspinulosum in the waters of Korea. Sequence divergence among all ' $C$.

115 euspinulosum' from GenBank sequences were also evaluated to provide a more accurate DNA-

116 based diversity assessment on the geographical and cryptic diversity of C. euspinulosum in the

117 Indo-Pacific region. As part of the study, a mini-review on global distribution of Cantellius species 
118 is presented and discussed with regard to management and conservation of the species diversity.

\section{Materials \& Methods}

\section{Field Study Permission}

122 Field collections in the present study were approved under permits (No. 2436, 2016) from

123 the National Institute of Biological Resources, Jeju Special Self-Governing Province.

125 Data collection

126 In total, nine sites were selected in the southern waters of the Jejudo Island to sample coral-

127 associated barnacles during August 2016 (Fig. 1). Specimens of C. cf. euspinulosum were collected 128 through SCUBA diving at depths of 5-20 m on Alveopora japonica corals (Figs. 2A-2C). Before 129 sampling coral-associated barnacles, the entire section of coral containing barnacles was

130 photographed in situ to identify the host corals. Small pieces of coral with embedded barnacles 131 (approximately $5 \times 5 \mathrm{~cm}$ ) were collected using a hammer and chisel. All barnacles and host corals 132 were preserved in $95 \%$ ethyl alcohol.

133 Cantellius cf. euspinulosum was isolated from A. japonica using forceps. The morphological

134 characteristics of shell parts (shells, scutum and tergum) and somatic bodies (six pairs of cirri, 135 penis, and oral cone) were examined. The shells and opercular valves (scutum and tergum) were 136 immersed in $1.5 \%$ bleach for approximately $5 \mathrm{~h}$ to digest the organic tissue completely. The shells 137 were then rinsed with slow-running purified water for $30 \mathrm{~min}$ and were air-dried. The shells, 138 scutum, and tergum were gold coated and observed under Scanning Electron Microscopes (SEM; 139 FEI Quanta 2000, Thermo-Scientific, Waltham, MA, USA). The cirri, penis, and oral cone were 140 dissected from the somatic bodies and examined using a light microscope (Zeiss Scope A1, Zeiss, 
141 Germany) with high definition lenses (Zeiss Plan APO Chromat 40X/0.95 and ZEISS Plan APO

142 Chromat 100x/1.4 oil). This approach allowed setal types on the cirri and mouth parts to be clearly

143 observed. Descriptions of setals follow those of Chan et al. (2008). Specimens were deposited in

144 Marine Arthropods Depository Bank of Korea (MADBK) of Seoul National University (SNU) and

145 Biodiversity Research Museum, Academia Sinica, Taiwan (ASIZCR).

146

147 Investigation of type specimens

148 According to Broch (1931), the type specimens of C. epinulosum (named as Creusia spinulosa

149 forma euspinulosa) were preserved in five bottles. The original description on the locations of the

150 specimens from Broch (1931) were detailed. First, Amboina, 3 m, coral bottom, February 10,

151 1922; several specimens, mostly dead, on the lower side of the Madreporian Herpetolitha sp.

152 Second, Amboina Bay, about 140 m, stones, February 22, 1922; several small specimens on dead,

153 corroded Madreprorarian corals. Third, St. 24.5³7'S, 13256'E, 100 m, hard bottom, April 15,

154 1922; several specimens in Madreporarian corals. Fourth, Singapore at low water (Consul Sc.

$155 \mathrm{Gad})$, June 14 1904; one specimen imbedded in the swollen distal end of a branched Madreporarian

156 coral. Fifth, off Jolo, 50 m, coral and Lithothamnia (Dr. Th. Mortensen), March 19, 1914; several

157 specimens in different Madreporarian corals (Figs. 3 and 4). All five specimens described by Broch

158 (1931) were successfully located in the Zoological Museum, University of Copenhagen, Denmark.

159 All specimens were dissected to examine the scutum and tergum.

160

\section{Phylogenetic analyses}

$162 \mathrm{COI}$ and $12 \mathrm{~S}$ sequences of the Cantellius cf. euspinulosum from Jejudo Island, Korea was already 
163 uploaded in GenBank from our earlier works and used to represent the new species from the 164 present study (Chan et al., 2018).

165 There are many mitochondrial gene sequences from coral-associated barnacles available in 166 GenBank. These mitochondrial markers, presented as C. cf. euspinulosum, make it possible to 167 compare species diversity data from the waters around the Jejudo Island with other available 168 mitochondrial sequences of C. euspinulosum globally. We downloaded all Cantellius sequences 169 obtained from the search query "Cantellius" in GenBank (Table S1).

170 DNA sequences were proofread using MEGA version 7.0 (Kumar et al., 2016), and were

171 aligned with the Cantellius sequences from GenBank through multiple alignment using MAFFT

172 version 6.717 (Katoh et al., 2002). Alignments were also checked thoroughly, and ambiguous

173 positions were adjusted manually. Gaps were inserted in some sequences due to missing data. A

174 matrix of genetic distances within and among species was generated using Kimura's two175 parameter model in MEGA version 7.0. The stability of clades was evaluated using bootstrap tests 176 with 1,000 replications. A maximum likelihood (ML) test was conducted for concatenated datasets 177 (mitochondrial COI $+12 \mathrm{~S}$ ). ML analysis was performed using RAxML-HPC2 on XSEDE 178 (Stamatakis, 2014) through the online server Cyberinfrastructure for Phylogenetic Research 179 (CIPRES) with the GTRGAMMA model of nucleotide substitution and 1,000 bootstrap replicates.

180 In the multigene analysis, alignments of two genes were concatenated, and were then partitioned 181 to gene regions. For the analysis, seven pyrgomatid species were used as the outgroup, and were 182 obtained from GenBank (Table S1).

183

\section{Zoobank registration}

185 The electronic version of this article in Portable Document Format (PDF) will represent a 
186 published work according to the International Commission on Zoological Nomenclature (ICZN),

187 and hence the new names contained in the electronic version are effectively published under that

188 Code from the electronic edition alone. This published work and the nomenclatural acts it contains

189 have been registered in ZooBank, the online registration system for the ICZN. The ZooBank

190 LSIDs (Life Science Identifiers) can be resolved and the associated information viewed through

191 any standard web browser by appending the LSID to the prefix http://zoobank.org/. The LSID for

192 this publication is:urn:Isid:zoobank.org:pub:4FCF5CC1-BC6B-4F22-A905-B9E1748E646C. The

193 online version of this work is archived and available from the following digital repositories: PeerJ,

194 PubMed Central and CLOCKSS.

195

196

\section{Results}

\section{Specimens of Cantellius euspinulosum from Broch (1931)}

198 The five bottles of specimens named "Creusia spinulosa forma euspinulosa” from Broch (1931)

199 contained multiple coral-associated barnacle species on examination of the shell and opercular 200 plates. The specimens from "Amboina, 3 m”, coral bottom. February 10th, 1922. Several 201 specimens, mostly dead, on the lower side of the Madreporian Herpetolitha sp." (first description 202 in section 2.2) were identified as Pyrgomina sp. This species has a fused external shell, with 203 balanoid type opercular plates. The specimens from "Off Jolo, 50 m" (fifth description in section 204 2.2), coral and Lithothamnia, (Dr. Th. Mortensen). March 19th, 1914. Several specimens in 205 different Madreporarian corals." were identified as Armatobalanus sp. This species has six shell 206 plates and balanoid type opercular plates. The bottle labelled with "Amboina Bay, about 140 m" 207 (second description in section 2.2), stones, February 22nd, 1922. "Several small specimens on 208 dead, corroded Madreprorarian corals.” did not contain any barnacle specimens for examination. 
209 Only two bottles of specimens were identified as C. euspinulosum. These included specimens

210 from 'St. $24.5^{\circ} 37$ 'S, $132^{\circ} 56^{\prime}$ E, $100 \mathrm{~m}$, hard bottom. April 15th, 1922. Several specimens in

211 Madreporarian corals" and "Singapore, at low water (Consul Sc. Gad). June 14th, 1904. One

212 specimen imbedded in the swollen distal end of a branched Madreporarian coral." (Figs. 3 and 4).

213 The scutum of both specimens was almost an equilateral triangular shape; external surfaces with

214 horizontal striations; occludent margin straight with fine teeth, tergal margin slightly convex; basal

215 margin convex, without any adductor plate and rostral tooth. A notch was present at $1 / 3$ of margin

216 close to the tergal margin, with a deep adductor muscle scar. The tergum had a slightly concaved

217 scutal margin and wide and blunt spur. Basal margin was slightly concaved (Figs. 3 and 4).

218

219 Molecular analysis

220 For the molecular analysis based on two genes (COI and 12S) sequences, 21 Cantellius species

221 including seven undetermined species (Cantellius sp.1-7) were downloaded from GenBank. The 222 adjusted alignments consisted of 639 bases for COI and 439 bases for 12S. To identify each species

223 accurately, we used concatenated tree (COI $+12 \mathrm{~S})$ datasets. Around $15 \%$ of partial sequences of

224 the $\mathrm{COI}$ and $1.8 \%$ of $12 \mathrm{~S}$ sequences were treated with gaps due to missing data. These datasets

225 were confirmed as 16 distinct taxa identified through clustering with previously reported species

226 (Fig. 5). Among them, two taxa were still undetermined and considered to be new species

227 (Cantellius sp.1 from Taiwan and Philippines and Cantellius sp.7 from Philippines). In the $C$.

228 arcuatus clade, 76 specimens were retrieved from GenBank, which originated from Japan,

229 Malaysia, Philippines, Papua New Guinea, and Korea. Of these, one ambiguously labelled as

230 "Cantellius sp.2" from the Philippines was confirmed as C. arcuatus. Three GenBank submissions

231 that were initially annotated in GenBank as C. sextus from Taiwan formed a unique clade. One 
232 specimen (UF8664) from the Philippines was grouped with C. septimus (sept1-3), as it had high

233 sequence similarities, and we defined it as C. septimus. The new Cantellius species in the present

234 study, Cantellius alveoporae sp. nov., based on nine GenBank sequence submissions originally

235 labeled as $C$. cf. euspinulosum from Korea, were consistently clustered as distinct sister clades to

236 the other two Cantellius species (C. brevitergum and C. septimus), with high nodal support that

237 was clearly demarcated. Therefore, we named them as "C. alveoporae sp. nov." (see taxonomic

238 description in section 3.3) in this study. Cantellius sp.5 (UF6541) and Cantellius sp.6 (UF8676)

239 from the Philippines formed a sister clade with C. transversalis (CEL_SU46_1) and C. acutum

240 (CEL_GI164_1, Taiwan and actu1), respectively. Therefore, we defined them as C. transversalis

241 and C. acutum. Cantellius sp.2 (UF8663, Philippines), forming a monophyletic group with $C$.

242 arcuatum (CEL_KT26_3 and CEL_KT101_3, Taiwan and arc1) and Cantellius sp.3 (UF8638,

243 Philippines), grouped with C. euspinulosum (CEL_KT14_1, CEL_KT16_1 and CEL_KT27_3,

244 Taiwan). These two groups were designated as $C$. arcuatum and C. euspinulosum. The remaining

245 five groups were monophyletic: C. pallidus, C. secundus, and C. hoegi originating from Taiwan,

246 C. cf. sumbawae and C. iwayama (Fig. 5).

247 Multigene sequence alignment revealed that the K2P distance among sequences ranged from $2483.28 \%$ to $10.24 \%$ in Cantellius spp. (Table S2). Of these, the new species in the present study,

249 Cantellius alveoporae sp. nov. (CEL_JJ08_02-04, CEL_JJ37_02-04, CEL_JJ39_01-03)

250 embedded in A. japonica, formed a sister clade with $C$. brevitergum with high sequence

251 divergences (Fig. 5). Their distant relationship was supported by the K2P distance, which was

$2525.27 \%$ (Table S2).

253 Cantellius alveoporae sp. nov. had similar morphology to C. euspinulosum. However, 254 phylogenetic analysis showed that it was not likely conspecific. Four sequences from GenBank, 
255 labelled as C. euspinulosum originating from Taiwan formed a sister clade with C. arcuatum. The 256 pairwise distance was $6.08 \%$ (Fig. 5, Table S2).

257

258 Description

259 Cantellius alveoporae sp. nov.

260 Cantellius cf. euspinulosum Chan et al., 2018: 5, figs 3-5.

261 Zoobank registry. urn:lsid:zoobank.org:act:F2A21CA9-CCBE-4C60-8B4A-98E3545792

262 E5

263 Materials examined. Holotype. Beom Seom, Is., Jejudo Island, Korea, on host coral Alveopora 264 japonica, coll. B.K.K. Chan, 10 August 2016 (MADBK 420501_001). Paratypes. numerous 265 specimens, Yongsuri, Hangyeong-myeon, Jeju-si, Jejudo Island, Korea, on host coral Alveopora 266 japonica, coll. K. S. Choi, 9 August 2016 (ASIZCR-000455); 5 specimens, Beom Seom, Is., Jejudo 267 Island, Korea, on host coral Alveopora japonica, coll. B.K.K. Chan, 10 August 2016 (MADBK 268 420501_002).

269 Size (Holotype). Basal diameter $6 \mathrm{~mm}$.

270 Diagnosis. Base of shell with 29 longitudinal septa, shell conical with 4 plates. Scutum triangular,

271 with rostral tooth and shallow adductor plate at basal margin, width almost equal to height, 272 occludent margin straight with strong teeth; tergum flat, thin, spur blunt. Mandible with 5 teeth, 273 fifth tooth fused with inferior angle; maxillule without notch; Labrum bilobed, 3 teeth on each 274 crest. Serrulate setae present on cirrus I to III; cirrus IV to VI long, slender. Penis annulated, longer 275 than cirrus VI.

276 Description. Shell conical and ovate, 4-plated (rostrum, carina, and paired laterals). External 277 surface covered by coral tissue. Base of shell with approximately 29 longitudinal septa radiating 
278 from rim of sheath to external shell surface ( 8 in rostrum and carina, 6 and 7 in laterals), septa

279 margin serrated. Orifice circular, about 2/5 length of rostro-carinal diameter (Fig. 2D).

280 Scutum and tergum separated, basically white, with purple color in apex region. Scutum

281 triangular, width approximately equal to height, occludent margin straight, rostral tooth and

282 adductor plate present. External surface with horizontal striations, striations with row of small

283 pores. Internal view with a deep depressor muscle crest, without an oval-shaped adductor muscle

284 scar. Tergum triangular. Spur blunt, width of basal margin of tergum equal to height of tergum.

285 External surface with a shallow medial furrow, extending from basal margin towards apex, width

286 of furrow increasing gradually from apex to base. External surface with horizontal striations (Fig.

$287 \quad 2 \mathrm{E})$.

288 Cirrus I with unequal rami, anterior ramus long, slender, with 12-segments, posterior ramus 9-

289 segmented, bearing serrulate setae (Fig. 6A). Cirrus II anterior ramus with 9-segments, slightly

290 longer than posterior ramus (7-segmented), bearing serrulate setae (Fig. 6B). Cirrus III anterior

291 ramus longer than posterior ramus, 12- and 9-segmented, respectively, bearing serrulate setae,

292 lacking small sharp teeth on base of each segment (Fig. 6C). Cirri IV-VI long, slender, rami similar

293 in length, bearing serrulate setae. Cirrus IV with anterior ramus 30-segmented, posterior ramus 31-

294 segmented, Cirrus V (anterior 30-segmented, posterior 31-segmented), Cirrus VI (anterior 32-

295 segmented, posterior 31-segmented). Each intermediate segment of ramus of Cirrus IV-VI with 2-

2963 pairs of short simple setae (Figs. 6D-6F). Penis annulated, with scattered short simple-type setae.

297 Pedicle with blunt basidorsal point (Figs. 6G-I).

298 Maxilla ovate, with serrulate setae on margin (Fig. 7A). Mandibular palp elongated, bearing

299 serrulate setae distally and on interior margin (Fig. 7B). Mandible with 5 teeth, excluding inferior

300 angle. First 3 teeth occupy $4 / 5$ length of cutting edge (Fig. 7C). Lateral surface, lower margin and 
301 cutting edge of mandible bearing simple-type setae (Fig. 7D). Lower margin short, inferior angle

302 blunt with simple-type setae (Fig. 7E). Maxillule cutting edge straight without notch, bearing row

303 of 9 large setae (Fig. 7F). Region close to cutting edge with dense simple-type setae, anterior and

304 posterior margins with simple-type setae (Figs. 7G and 7H). Labrum bilobed, lobes separated by

305 a V-shaped notch, 3 sharp teeth on each side of notch (Figs. 7I and 7J).

306 Habitat. Grows on host coral A. japonica. The species located below the extended polyps of

307 Alveropora. The barnacles can be located after disturbing the coral polyps to allow them retract

308 into the skeleton, exposing the barnacles when the shelter of the active polyps is removed (Figs.

309 2A-2C).

310 Distribution. At present only recorded in Jejudo Island, Korea.

311 Etymology. Denotes growing on its host $A$. japonica in Korean waters.

312 Remarks. After examining the type specimens of C. euspinulosum, C. alveoporae sp. nov. differs

313 to C. euspinulosum (Broch, 1931) in the morphological characteristics of the scutum and tergum:

314 (1) the scutum has a rostral tooth in C. alveoporae sp. nov., (2) basal margin has a shallow adductor

315 plate in C. alveoporae sp. nov., (3) tergal spur sharp and thin in C. alveoporae sp. nov., and (4)

316 Basal margin of tergum forms a strong V-shaped in C. alveoporae sp. nov. Based on these

317 differences, the specimens from Korea were assigned as a new species.

318

319 Discussion

320 Historical remarks on the Cantellius taxonomy

321 The present study reported the first examination of the type specimens of $C$. euspinulosum,

322 providing baseline information for identifying it, along with morphologically close species. The

323 morphology of type specimen of C. euspinulosum described by Broch (1931) matched the 
324 illustration of Creusia spinulosa var. 1 by Darwin. This result supports the conclusion of Broch

325 (1931) that the forma euspinulosum represents the Creusia spinulosa var. 1 of Darwin. By

326 combining morphological and molecular approaches to examine morphological variation in the

327 opercular plates of C. euspinulosum and sequences divergences, we potentially discovered five

328 cryptic species of C. euspinulosum. Each cryptic species had different morphological characters

329 in the opercular plates and with respect to geographical distribution.

330 Based on the morphology of specimens in the opercular plates, the first group of species was

331 considered as C. euspinulosum (Broch, 1931). This group encompassed specimens from Java,

332 Indonesia (Darwin, 1854), Singapore (Broch, 1931), Mergui Archipelago in the Andaman Sea

333 (Nilsson-Cantell, 1938), and Nha Trang, Vietman (Poltarukha \& Dautova, 2018). This group

334 represents the C. spinulosa var. 1 described by Darwin (Fig. 8). The opercular plates were similar

335 to the type specimens examined in the present study. The scutum lacked a rostral tooth and

336 adductor plate on the basal margin. The tergum had a broad spur. Host corals recorded by these

337 studies included Acropora, Favia, Favites, Leptoria, Montipora, Pchyseris, and Pocillipora

338 (Nilsson-Cantell, 1938; Poltarukha \& Dautova, 2018). Thus, C. euspinulosum is likely a generalist

339 species distributed in the Indo-Pacific region (Fig. 8A).

340 Nilsson-Cantell (1938) described the specimens of C. euspinulosum from the Moscos Islands

341 in the Andaman Sea. The scutum of this species has a rostral tooth on the basal margin of the

342 scutum, similar to the specimens from the Jejudo Island in Korea, Ogasawara in Japan, and Palau.

343 However, this specimen had a curved spur on the tergum, contrasting with the specimens collected

344 from Korea, Japan, and Palau. Thus, it might be another cryptic species specific to the Indian

345 Ocean (Fig. 8B).

346 Anderson (1992) reported C. euspinulosum from New South Wales, Australia. The scutum of 
347 this species has a rostral tooth, but the tergum is arrow-shaped (Fig. 8C). Thus, it might represent

348 another cryptic species present in the Pacific waters of Australia. However, to date, there are no

349 available GenBank sequences of Cantellius collected from this region.

350 Chan et al. (2013) described C. euspinulosum originating from Taiwan. The illustration of the

351 scutum showed that the basal margin does not contain an inconspicuous or minute rostral tooth;

352 however, the depressor muscle region is wide and well-developed. The species is mostly found in 353 the coral Porites (Chan et al., 2013). The presence of a separate molecular clade for this species 354 suggests it is another cryptic species (Figs. 5 and 8D).

355 The last group included C. alveoporae sp. nov. identified around the Jejudo Island. (Fig. 8E;

356 present study; Chan et al., 2018). This group might also be represented by C. euspinuloum reported

357 from Palau (Hiro, 1937b) and Ogasawara, Japan (Ogawa \& Tachikawa, 2009; Fig. 8E). These 358 specimens had a rostral tooth and adductor plate on the basal margin of the scutum, and grow 359 exclusively on the coral Alveopora spp. (Fig. 8E). Thus, this species is likely a specialist on 360 Alveopora that is distributed in Pacific waters. Molecular studies by Kang et al. (2020) showed 361 that clear genetic population differentiation exists for A.japonica coral among Taiwan, Korea, and

362 Japan. Thus, these corals are likely present in all three regions at geological time scales, with

363 limited gene flow across regions. Whether their epibiont $C$. alveoporae sp. nov. exhibits similar

364 levels of population differentiation requires further investigation by collecting samples from 365 different geographical regions.

367 Distributions of Cantellius species and ecological implications

368 The genus Cantellius is only present in the Indo-Pacific region. From reviewing the global 369 distribution records of Cantellius (Fig. 9), the representative species diversity could be seen from 
370 several countries encompassing Japan (13species), Taiwan (11 species), Palau (10 species), the

371 Philippines (7 species), and Singapore (5 species), in order. Such result might be resulted from

372 more extensive sampling effort in some specific regions followed by fine taxonomy works on coral

373 barnacles (Hiro, 1935; Hiro, 1937a; Hiro, 1937b; Chan et al., 2013; Utinomi, 1962). Meantime,

374 climate condition and management practices on sustaining coral habitats would also be 375 acknowledged.

376 All other countries showed relatively lower species diversity in Cantellius, with maximum of

377 three Cantellius species being documented. The occurrence of at least one species was reported

378 from the Andaman Island, Australia, Hong Kong, Indian Ocean, Korea, the Banda Sea, Malaysia,

379 Papua New Guinea, and Seychelles. A lesser species diversity in these areas would be collectively

380 explained by inadequate study, sampling endeavor, decreasing population of host corals, etc.

381 Cantellius alveoporae sp. nov. was identified in the present study, and is a specialist on $A$.

382 japonica coral. Alveopora japonica is high latitude coral that is distributed in the waters of southern

383 Taiwan, the Jejudo Island, Korea, and around the Honshu Island, Japan (Veron, 2002). This coral

384 is an important foundation species on high latitude coral reefs, and forms secondary habitats for

385 other species, including coral barnacles (Noseworthy et al., 2016). Under the effect of global

386 climatic change, the water temperature of the west Pacific is increasing, particularly in the waters

387 around Korea. Over the last 51 years, the water temperature in the Pacific has increased by 1.23

$388{ }^{\circ} \mathrm{C}$, while that around Korea is 2.5 times greater than the global trend (Belkin, 2009; Han \& Lee, $3892020)$.

390 Recent studies documented that current global warming might increase the recruitment and

391 abundance of $A$. japonica around Korea (Denis et al., 2015; Vieira et al., 2016). Thus, the

392 abundance of $C$. alveoporae sp. nov. would be also expected to increase with that of $A$. japonica. 
393 Phylogenetic analysis of the coral A. japonica collected from the southern waters of Japan, Jejudo

394 Island in Korea, and Taiwan showed that Alveopora forms three molecular clades matching these

395 three regions (Kang et al., 2020). Thus, A. japonica in Korea would have established over a long

396 geological history. Therefore, the coral barnacle C. alveoporae sp. nov. might exhibit genetic

397 divergence in Japan, Korea, and other Pacific locations, with DNA-based assessments being

398 required to confirm this hypothesis.

399 Meantime, the current global climatic changes and the bleaching events of corals in the Pacific,

400 including Korean waters, might impact both corals and coral symbiotic fauna. As the coral reef

401 assemblages on the Jejudo Island, Korea is marginal community, Cantellius diversity would be

402 limited to the southern part of the Korean coastal waters. Accordingly, a drastic effect on the

403 diversity of Cantellius would be prospected. Such impact would increase for those especially

404 having narrower latitudinal distribution for C. hoegi and C. brevitergum which presently recorded

405 in Taiwan and Palau only, respectively. Further studies on diversity and biogeography of coral

406 barnacles should be conducted in the coral triangle region, and only knowing more on the detailed

407 diversity pattern can allow better management and prediction of future diversity of coral associated

408 barnacles in the Indo-Pacific region (Tittensor et al., 2010).

\section{Acknowledgements}

411 We would like to thank prof Kwang-Sik Choi (School of Marine Biomedical Science, Jeju

412 National University) for assisting with field collection. The authors would like to thank the

413 reviewers, Christine Ewers-Saucedo and the other anonymous reviewer for giving constructive

414 comments on the MS. Thanks to Danny Eibye-Jacobsen and Niklas Dreyer for arranging museum

415 loans of specimens from Zoological Museum, University of Copenhagen, Denmark. 


\section{Additional Information and Declaration}

\section{Funding}

419 This work was supported by the projects entitled "Ecosystem-Based Analysis and Decision420 Making Support System Development for Marine Spatial Planning [grant number 20170325]" 421 funded by the Ministry of Oceans and Fisheries, Korea.

\section{Grant Disclosures}

423 The following grant information was disclosed by the authors:

424 The Ministry of Oceans and Fisheries of Korea: 20170325.

425 Competing Interests

426 The authors declare there are no competing interests.

\section{Author Contributions}

428 - Hyun Kyong Kim and Benny K.K. Chan conceived and designed the experiments, performed the 429 experiments, analyzed the data, prepared figures and/or tables, authored or reviewed drafts of the 430 paper, and approved the final draft.

431 - Sung Joon Song analyzed the data, authored or reviewed drafts of the paper, and approved the 432 final draft.

433 - Jong Seong Khim analyzed the data, authored or reviewed drafts of the paper, funding acquisition 434 and approved the final draft.

\section{Data Availability}

436 The following information was supplied regarding data availability:

437 Sequences are available for review in the Supplementary File.

\section{Supplemental Information}


439 Supplemental information for this article can be found online at http://dx.doi.org/ 440

\section{References}

442 Achituv Y, Tsang LM, Chan BKK. 2009. A new species of Cantellius and a

443 redescription of C. sextus (Hiro, 1938) (Cirripedia, Balanomorpha Pyrgomatidae) from the 444 elephant skin coral, Pachyseris speciosa (Dana, 1846) (Scleractinia, Agariciidae) from Taiwan. Zootaxa 2022:15-28.

Achituv Y. 2001. Cantellius alphonsei n. sp., a new coral-inhabiting barnacle (Cirripedia, Pyrgomatinae) of Montipora. Crustaceana 74:617-626 DOI 10.1163/15685400175037 7894.

Asami K, Yamaguchi T. 1997. Distribution of living and fossil coral barnacles (Cirripedia; Pyrgomatidae) in Japan. Sessile Organism 14:9-16 DOI 10.4282/sosj.14.9.

451

452

453

454

455

456

Anderson DT. 1992. Structure, function and phylogeny of coral-inhabiting barnacles (Cirripedia, Balanoidea). Zoological Journal of the Linnean Society 106:277-339 DOI 10.1111/j.1096-3642.1992.tb01249.x.

Belkin IM. 2009. Rapid warming of large marine ecosystems. Progress in Oceanography 81:207-213 DOI 0.1016/j.pocean.2009.04.011.

Broch H. 1931. Papers from Dr. Th. Mortensen's Pacific Expedition 1914-16. LVI. Indomalayan Cirripedia. Videnskabelige meddelelser fra den Naturhistoriske forening Kjobenhavn 91:1-146.

Chan BKK, Garm A, Høeg JT. 2008. Setal morphology and cirral setation of thoracican barnacle cirri: adaptations and implications for thoracican evolution. Journal of Zoology 275:294-306 DOI 10.1111/j.1469-7998.2008.00441.x. 
462 Chan BKK, Chen YY, Achituv Y. 2013. Crustacean fauna of Taiwan: Barnacles, vol II-

463 Cirripedia: Thoracica: Pyrgomatidae. Taipei: Biodiversity Research Center, Academia $464 \quad$ Sinica Press.

465 Chan BKK, Høeg JT. 2015. Diversity of lifestyles, sexual systems, and larval development 466 patterns in sessile crustaceans. Lifestyles and Feeding Biology 14-34.

467 Chan BKK, Xu G, Kim HK, Park J-H, Kim W. 2018. Living with marginal coral communities: Diversity and host-specificity in coral-associated barnacles in the northern coral distribution limit of the East China Sea. PloS ONE 13: e0196309 DOI

Chan BKK, Wong KJ, Cheng YR. 2020. Biogeography and host usage or coralassociated crustaceans: barnacles, copepods and gall crabs as models. The Natural History of the Crustacea: Evolution and Biogeography of the Crustacea (Volume 8).

Chen HN, Tsang LM, Chong VC, Chan BKK. 2014. Worldwide genetic differentiation in the common fouling barnacle, Amphibalanus amphitrite. Biofouling 30:1067-1078 DOI 10.1080/08927014.2014.967232.

Darwin C. 1854. A monograph on the sub-class Cirripedia with figures of all the species. The Balanidae, the Verrucidae, etc. London: Royal Society.

Denis V, Ribas-Deulofeu L, Loubeyres M, De Palmas S, Hwang SJ, Woo S, Song JI, Chen C A. 2015. Recruitment of the subtropical coral Alveopora japonica in the temperate waters of Jeju Island, South Korea. Bulletin of Marine Science 91:85-96 DOI 10.5343/bms.2014.1032. 
crustaceans: an introduction. Journal of Crustacean Biology 40:761-764 DOI 10.1093/jcbiol/ruaa082.

Goldberg WM. 2013. The biology of reefs and reef organisms. Illinois:University of Chicago

487 Press.

Han IS, Lee JS. 2020. Change the Annual Amplitude of Sea Surface Temperature due to Climate Change in a Recent Decade around the Korean Peninsula. Journal of the Korean Society of Marine Environment \& Safety 26:233-241 DOI 10.7837/kosomes.2020.26.3.233.

Hiro F. 1935. A study of cirripeds associated with corals occurring in Tanabe Bay. Oceanogr. Records of Oceanographic Works in Japan 7:1-28.

Hiro F. 1937a. Studies on Cirripedian Fauna of Japan (II): Cirripeds found in the Vicinity of the Seto Marine Biological Laboratory. Memoirs of the College of Science, Kyoto Imperial University 12:385-478.

Hiro F. 1937b. Cirripeds of the Palao Islands. Palao Tropical biological Statiton Studies 1:3772

\section{Kang JH, Jang JE, Kim JH, Kim S, Keshavmurthy S, Agostini S, Reimer JD, Chen CA,}

Choi KS, Park SR, Lee HJ. 2020. The origin of the subtropical coral Alveopora japonica (Scleractinia: Acroporidae) in high-latitude environments. Frontiers in Ecology and Evolution 8: 12 DOI 10.3389/fevo.2020.00012.

Katoh K, Misawa K, Kuma KI, Miyata T. 2002. MAFFT: a novel method for rapid multiple sequence alignment based on fast Fourier transform. Nucleic acids research 30:3059-3066 DOI 10.1093/nar/gkf436. 
506 Kim IH. 2011. Invertebrate Fauna of Korea. Vol. 21: Barnacles. Seoul: National Institute of 507 Biological Resources, Ministry of Environment.

508 Kolbasov GA, Chan BKK, Petrunina AS. 2015. Gorgonolaureus bicornutus sp. nov.

509 (Crustacea: Thecostraca: Ascothoracida) from off south-east Taiwan with notes on

510 morphology and distribution. Zootaxa 3972: 328-342 DOI 10.11646/zootaxa.3972.3.2.

511 Kolbasov GA, Chan BKK, Molodtsova TN, Achituv YAIR. 2016. Revision of the coralinhabiting genus Conopea (Cirripedia: Archaeobalanidae) with description of two new species of the genera Conopea and Acasta. Zootaxa 4178:182-208 DOI 10.11646/zootaxa.4178.2.2.

Kumar S, Stecher G, Tamura K. 2016. MEGA7: molecular evolutionary genetics analysis version 7.0 for bigger datasets. Molecular Biology and Evolution 33:1870-1874 DOI 10.1093/molbev/msw054.

Malay MCMD, Michonneau F. 2014. Phylogenetics and morphological evolution of coraldwelling barnacles (Balanomorpha: Pyrgomatidae). Biological Journal of the Linnean Society 113:162-179 DOI 10.1111/bij.12315.

Newman WA, Ross A. 1976. Revision of the balanomorph barnacles: including a catalog of the species. Memoirs of the San Diego Society of Natueal History 9:1-108.

Nilsson-Cantell CA. 1938. Cirripedes from the Indian Ocean in the collection of the Indian Museum, Calcutta. Memoirs of the Indian Museum 13:1-81. Choi KS. 2016. An assemblage of mollusks associated with the high latitude scleractinian coral Alveopora japonica (Eguchi 1968) in Jeju Island, off the south coast of Korea. Ocean 
529 Ogawa K, Matsuzkai K. 1992. An essay on host specificity, systematic taxonomy, and evolution of the coral-barnacles. Bulletin of the Biogeographical Society of Japan 47:87101.

Ogawa K, Tachikawa H. 2009. Coral-Inhabiting barnacles from the Ogasawara Islands. Bulletin of the Biogeographical Society of Japan 64:89-96.

Poltarukha OP, Dautova TN. 2018. Barnacles (Cirripedia, Thoracica) of Nhatrang Bay. Донная фауна залива Нячанг, Южный Вьетнам/Benthic fauna of the Bay of Nhatrang, Southern Vietnam, 89.

Roberts CM, McClean CJ, Veron JE, Hawkins JP, Allen GR, McAllister DE, Mittermier C biodiversity hotspots and conservation priorities for tropical reefs. Science 295:1280-1284

Ross A, Newman WA. 1973. Revision of the coral-inhabiting barnacles (Cirripedia: Balanidae). DOI 10.1126/science.1067728.

Simon-Blecher N, Huchon D, Achituv Y. 2007. Phylogeny of coral-inhabiting barnacles Transactions of the San Diego Society of Natural History 17:137-174.

Stamatakis A. 2014. RAxML version 8: a tool for phylogenetic analysis and post-analysis of large phylogenies. Bioinformatics 30:1312-1313 DOI 10.1093/bioinformatics/btu033.

Stella JS, Pratchett MS, Hutchings PA, Jones GP. 2011. Coral-associated invertebrates: 
Marine Biology: An Annual Review 49:43-104.

551 Tittensor DP, Mora C, Jetz W, Lotze HK, Ricard D, Berghe EV, Worm B. 2010. Global patterns and predictors of marine biodiversity across taxa. Nature 466:1098-1101.

Tsang LM, Chan BKK, Shih FL, Chu KH, Allen Chen CA. 2009. Host-associated speciation in the coral barnacle Wanella milleporae (Cirripedia: Pyrgomatidae) inhabiting the Millepora coral. Molecular Ecology 18:1463-1475 DOI 10.1111/j.1365294X.2009.04090.x.

Tsang LM, Chu KH, Nozawa Y, Chan BKK. 2014. Morphological and host specificity evolution in coral symbiont barnacles (Balanomorpha: Pyrgomatidae) inferred from a multi-locus phylogeny. Molecular Phylogenetics and Evolution 77:11-22 DOI 10.1016/j.ympev.2014.03.002.

Utinomi H. 1962. Studies on the Cirripedian fauna of Japan-VIII. Thoracic Cirripeds from western Kyusyu. Publications of the Seto Marine Laboratory, 10, 211-239.

Veron JEN. 2002. New species described in Corals of the World (Vol. 11). Australian Institute of Marine Science: Townsville.

\section{Vieira C, Keshavmurthy S, Ju SJ, Hyeong K, Seo I, Kang CK, Hong HK, Chen CA, Choi} KS. 2016. Population dynamics of a high-latitude coral Alveopora japonica Eguchi from Jeju Island, off the southern coast of Korea. Marine and Freshwater Research 67:594-604 DOI 10.1071/MF14330.

Zweifler A, Simon-Blecher N, Pica D, Chan BKK, Roth J, Achituv Y. 2020. A stranger among us: the occurrence of Cantellius (Balnoidea: Pyrgomatidae) an epibiont of scleractinias in stylasterids (Hydrozoa). Zoological Journal of the Linnean Society 
190:1077-1094 DOI 10.1093/zoolinnean/zlaa017. 


\section{Figure captions}

574 Figure 1 Collection sites of Cantellius alveoporae sp. nov. Korean Peninsula. (A) Collection sites showing the location of the Jejudo Island; (B) Jejudo Island, showing the locations of collections sites; (C) Yongsuri; (D) Beomseom Is. and (E) Seopseom Is. Coral species were listed under each island name in (B) to show the coral distribution. Map data (C) 2021 Google map.

Figure 2 Photographs of Cantellius alveoporae sp. nov. (A-C) In-situ underwater photographs of Cantellius alveoporae sp. nov. barnacles on the host coral Alveopora japonica (Jejudo Island, Korea), indicated by white circles; (D) SEM investigations on the external and internal view of the Cantellius alveoporae shell; (E) external and internal view of the scutum and tergum of Cantellius alveoporae (MADBK 420501_001, Holotype); (F)

Figure 3 Cantellius euspinulosum specimen from Broch's collection, Zoological Museum, external and internal view of the scutum and tergum of Cantellius alveoporae (ASIZCR000455, Paratype). RT - Rostral Tooth, AP - Adductor Plate. Broch and with Broch's signature; (B) a piece of host coral, Madreporarian coral, with one Cantellius euspinulosum barnacle specimen attached to it; (C)external view of the scutum and tergum of Cantellius euspinulosum; (D) internal view of the scutum and tergum of Cantellius euspinulosum.

Figure 4 Cantellius euspinulosum the second specimen from Broch's collection, Zoological Museum, University of Copenhagen, Denmark. (A) Specimen label of the specimens described by Broch and with Broch's signature; (B) a piece of host coral, Madreporarian coral with one Cantellius euspinulosum barnacle specimen attached to it; (C) internal view 
of the scutum and tergum of Cantellius euspinulosum; (D) scanning electron micrograph showing the external view of the scutum and tergum of Cantellius euspinulosum; (E) scanning electron micrograph showing the internal view of the scutum and tergum of Cantellius euspinulosum.

Figure 7 Trophi of Cantellius alveoporae sp. nov. (MADBK 420501_001), holotype. (A)

Figure 5 Phylogenetic tree $(\mathrm{COI}+12 \mathrm{~S})$ for coral-associated barnacles based on maximum likelihood (ML) analysis of the two mitochondrial gene datasets. ML trees were constructed with RaxML 8.0.2 using the GTRGAMMA model of evolution and 1,000 bootstrap replicates. Bootstrap scores of $>80 \%$ are shown at the nodes. Cantellius euspinulosum species reported in Taiwan are presented in green, and new species from this study are presented in pink. The scale bar represents the number of expected nucleotide substitutions per site.

Figure 6 Cirri and penis of Cantellius alveoporae sp. nov. (MADBK 420501_001)

, holotype. (A) Cirrus I; (B) cirrus II; (C) cirrus III; (D) cirrus IV; (E) cirrus V; (F) cirrus VI; $(\mathrm{G})$ penis; $(\mathrm{H})$ basidorsal point of penis; (I) tip of penis. Maxilla (a); (B) mandibular palp; (C) mandible; (D) inferior margin of mandible; (E) lower margin with simple-type setae of mandible; (F) maxillule; $(\mathrm{G})$ large simpletype setae on cutting edge; (H) simple-type setae on cutting edge; (I) labrum; (J) teeth

Figure 8 Scanning electron micrographs and revised drawings from previous published on the labrum. Cantellius alveoporae sp. nov. Illustration credits: Benny K.K. Chan. 
including three species in Korea. Map template credit: Hyun Kyong Kim. 


\section{Figure 1}

Figure 1 Collection sites of Cantellius alveoporae sp. nov. Korean Peninsula.

(A) Collection sites showing the location of the Jejudo Island; (B) Jejudo Island, showing the locations of collections sites; (C) Yongsuri; (D) Beomseom Is. and (E) Seopseom Is. Coral species were listed under each island name in (B) to show the coral distribution.

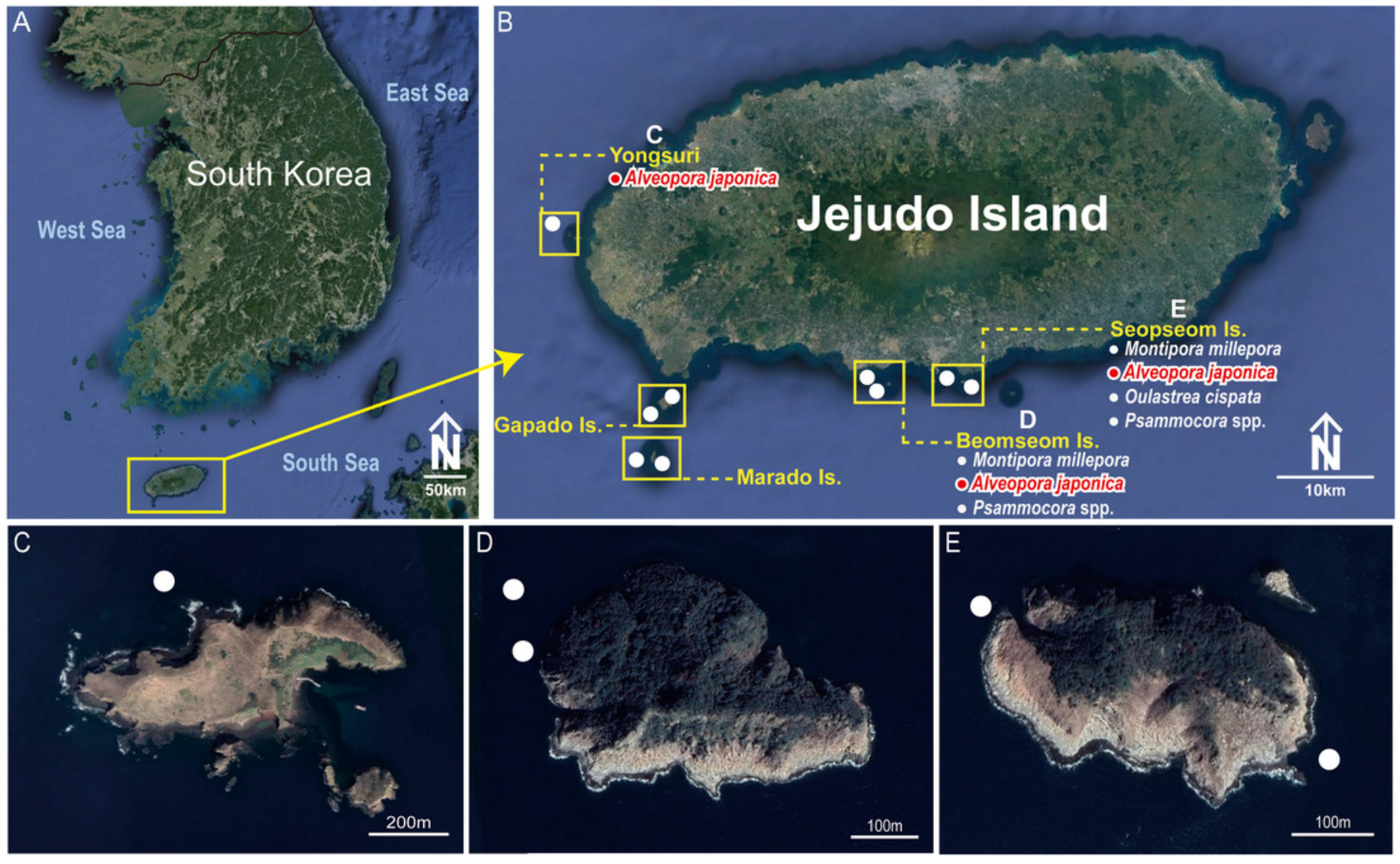




\section{Figure 2}

Figure 2 Photographs of Cantellius alveoporae sp. nov.

(A-C) In-situ underwater photographs of Cantellius alveoporae sp. nov. barnacles on the host coral Alveopora japonica (Jejudo Island, Korea), indicated by white circles; (D) SEM investigations on the external and internal view of the Cantellius alveoporae shell; (E) external and internal view of the scutum and tergum of Cantellius alveoporae (MADBK 420501_001, Holotype); (F) external and internal view of the scutum and tergum of Cantellius alveoporae (ASIZCR-000455, Paratype). RT - Rostral Tooth, AP - Adductor Plate. 

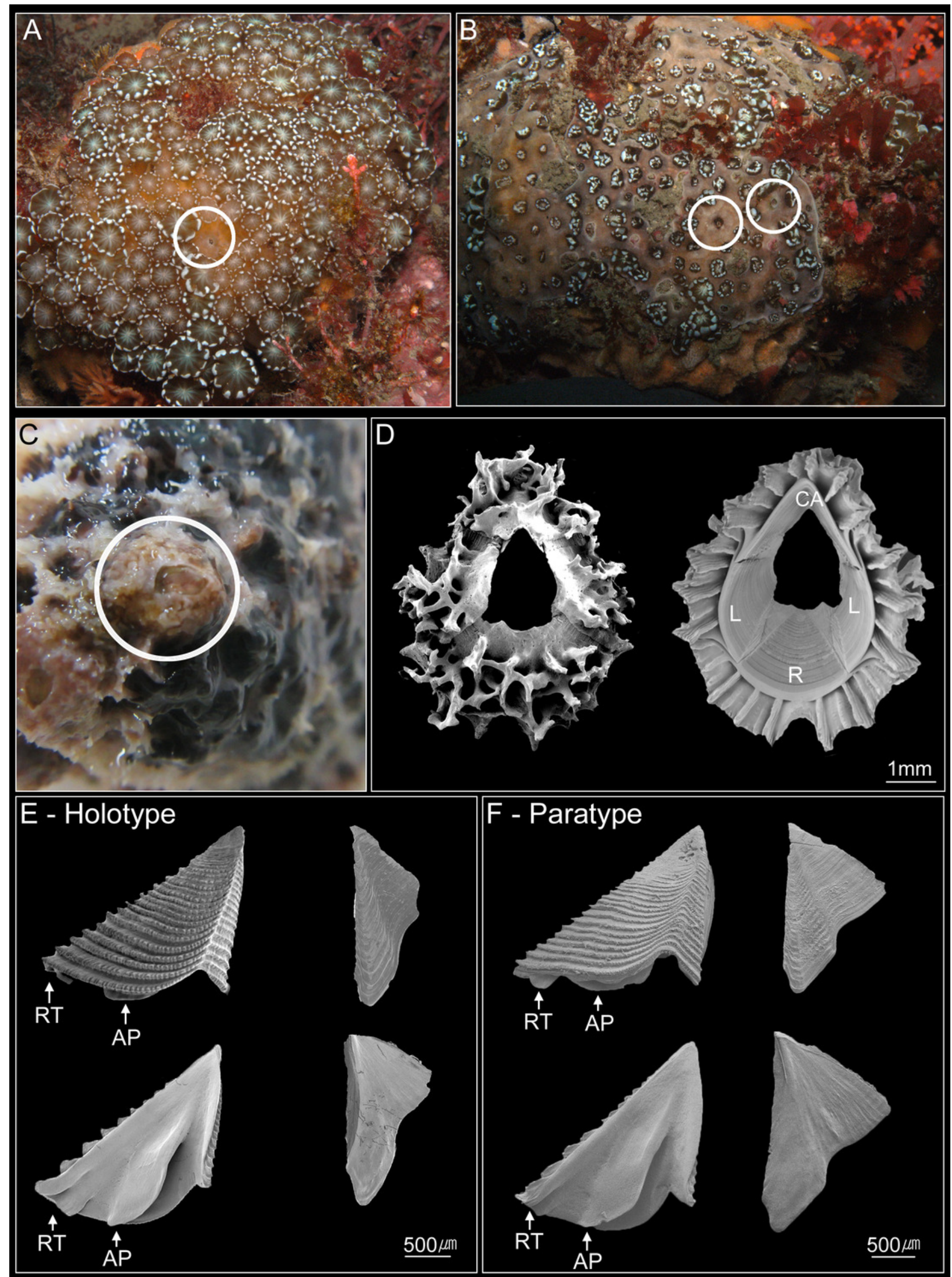


\section{Figure 3}

Figure 3 Cantellius euspinulosum specimen from Broch's collection, Zoological Museum, University of Copenhagen, Denmark.

(A) Specimen label of the specimens described by Broch and with Broch's signature; (B) a piece of host coral, Madreporarian coral, with one Cantellius euspinulosum barnacle specimen attached to it; (C)external view of the scutum and tergum of Cantellius euspinulosum; (D) internal view of the scutum and tergum of Cantellius euspinulosum.

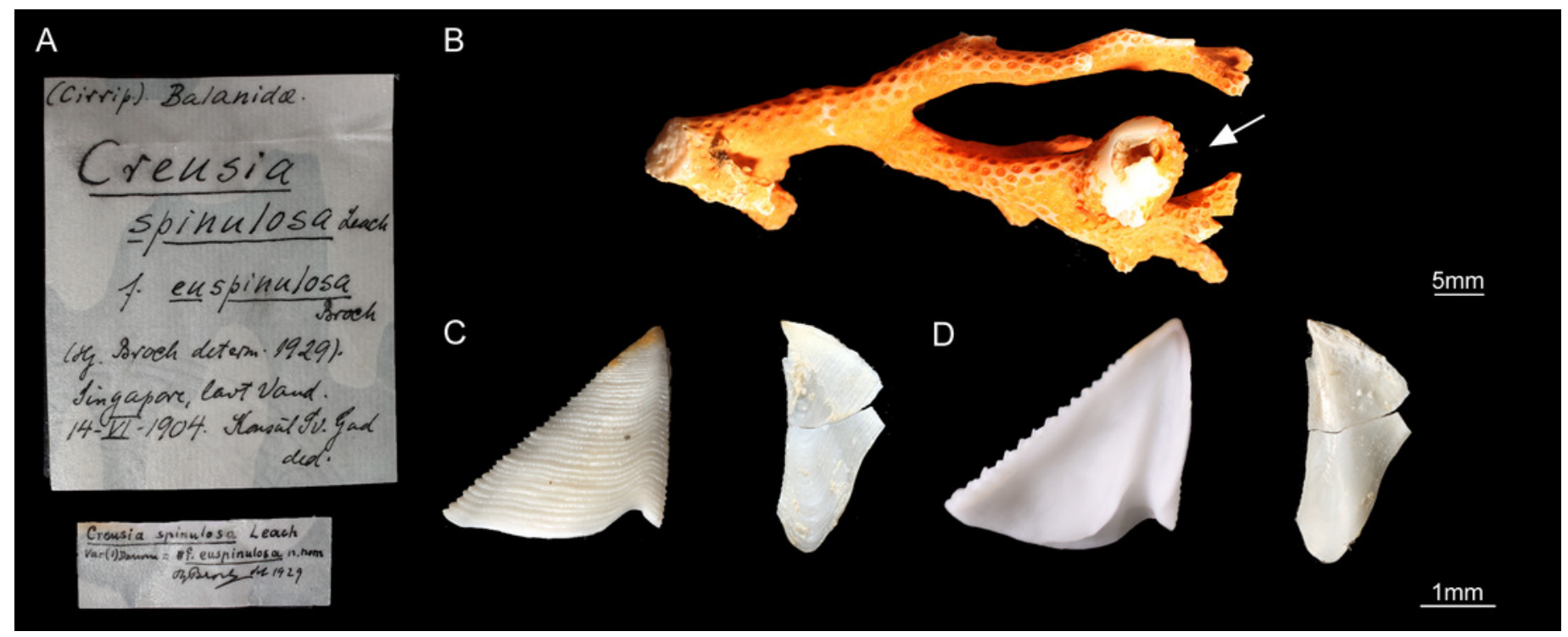




\section{Figure 4}

Figure 4 Cantellius euspinulosum the second specimen from Broch's collection, Zoological Museum, University of Copenhagen, Denmark.

(A) Specimen label of the specimens described by Broch and with Broch's signature; (B) a piece of host coral, Madreporarian coral with one Cantellius euspinulosum barnacle specimen attached to it; (C) internal view of the scutum and tergum of Cantellius euspinulosum; (D) scanning electron micrograph showing the external view of the scutum and tergum of Cantellius euspinulosum; (E) scanning electron micrograph showing the internal view of the scutum and tergum of Cantellius euspinulosum.

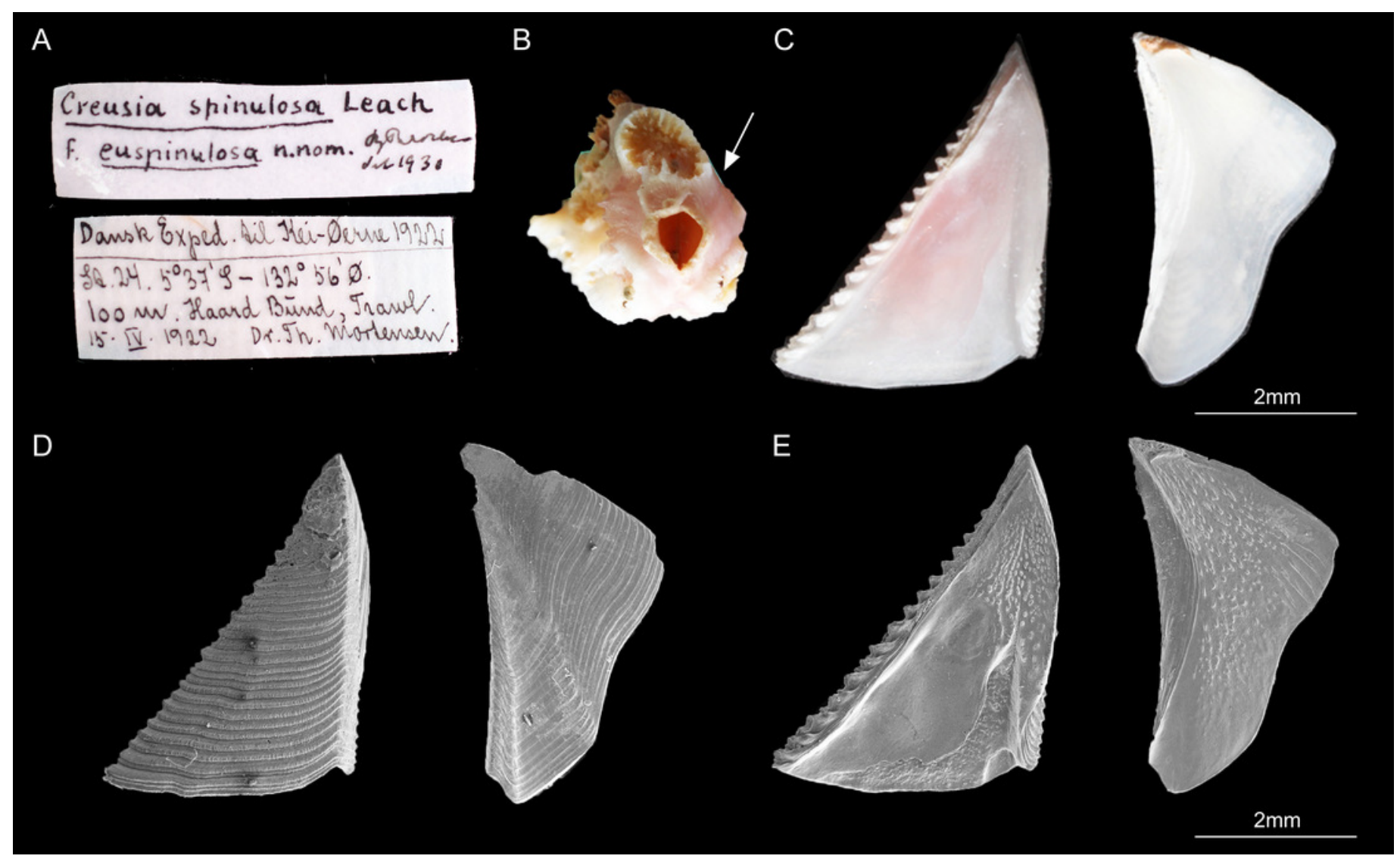




\section{Figure 5}

Figure 5 Phylogenetic tree $(\mathrm{COI}+12 \mathrm{~S})$ for coral-associated barnacles based on maximum likelihood (ML) analysis of the two mitochondrial gene datasets.

ML trees were constructed with RaxML 8.0.2 using the GTRGAMMA model of evolution and 1,000 bootstrap replicates. Bootstrap scores of $>80 \%$ are shown at the nodes. Cantellius euspinulosum species reported in Taiwan are presented in green, and new species from this study are presented in pink. The scale bar represents the number of expected nucleotide substitutions per site. 


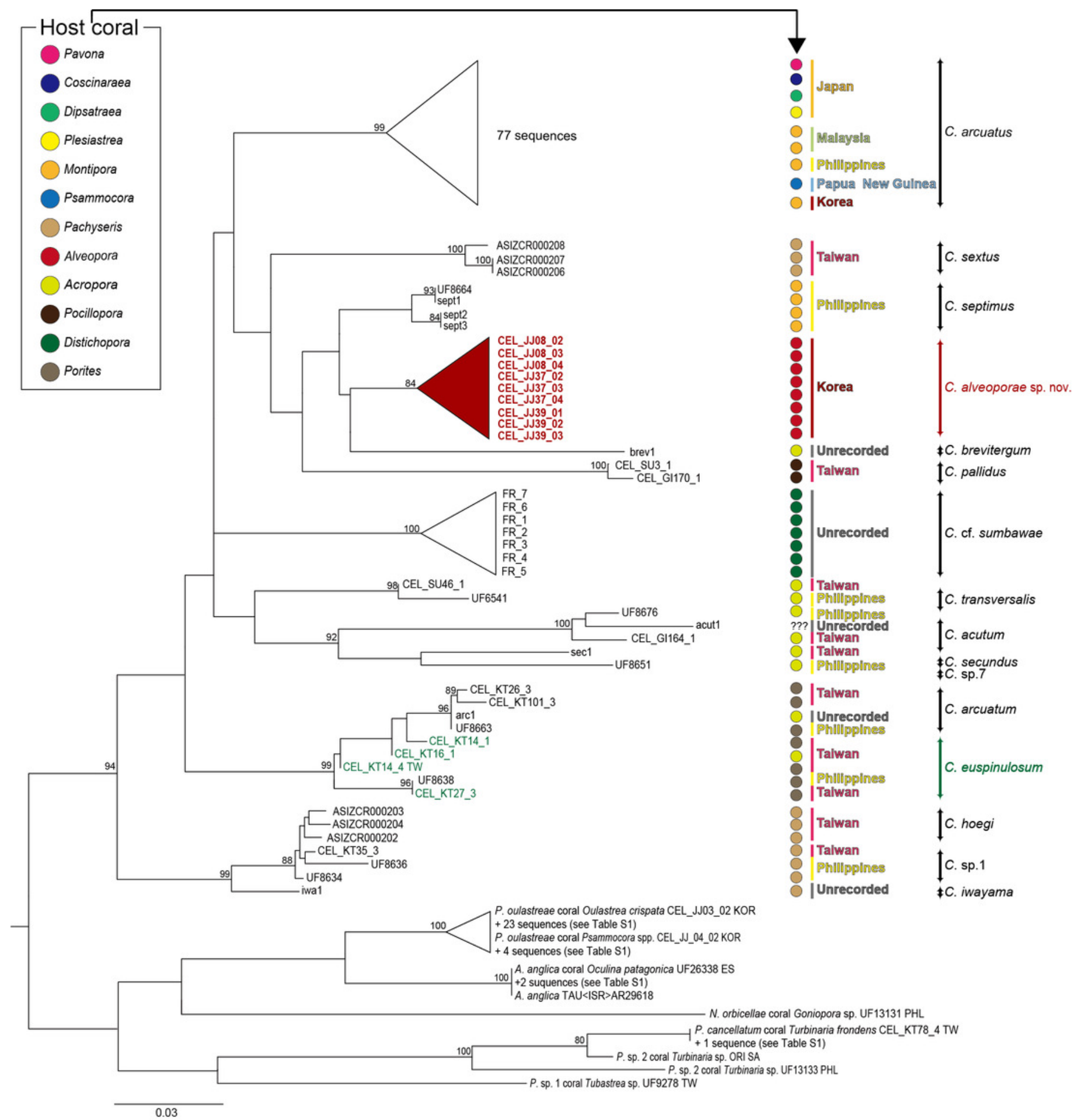


Figure 6

Figure 6 Cirri and penis of Cantellius alveoporae sp. nov. (MADBK 420501_001), holotype.

(A) Cirrus I; (B) cirrus II; (C) cirrus III; (D) cirrus IV; (E) cirrus V; (F) cirrus VI; (G) penis; (H) basidorsal point of penis; (I) tip of penis. 

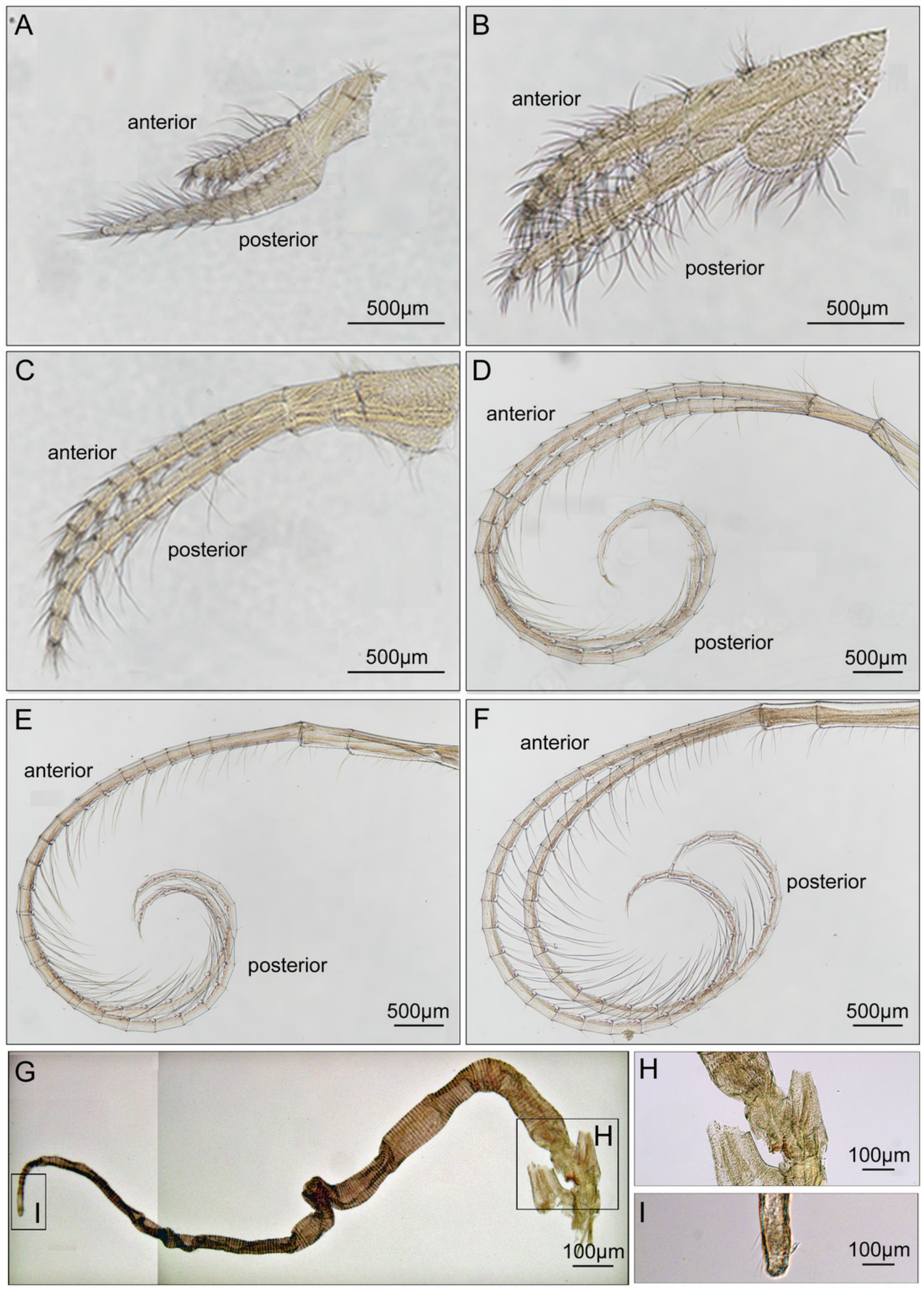


\section{Figure 7}

Figure 7 Trophi of Cantellius alveoporae sp. nov. (MADBK 420501_001), holotype.

(A) Maxilla (a); (B) mandibular palp; (C) mandible; (D) inferior margin of mandible; (E) lower margin with simple-type setae of mandible; (F) maxillule; (G) large simple- type setae on cutting edge; (H) simple-type setae on cutting edge; (I) labrum; (J) teeth on the labrum. 

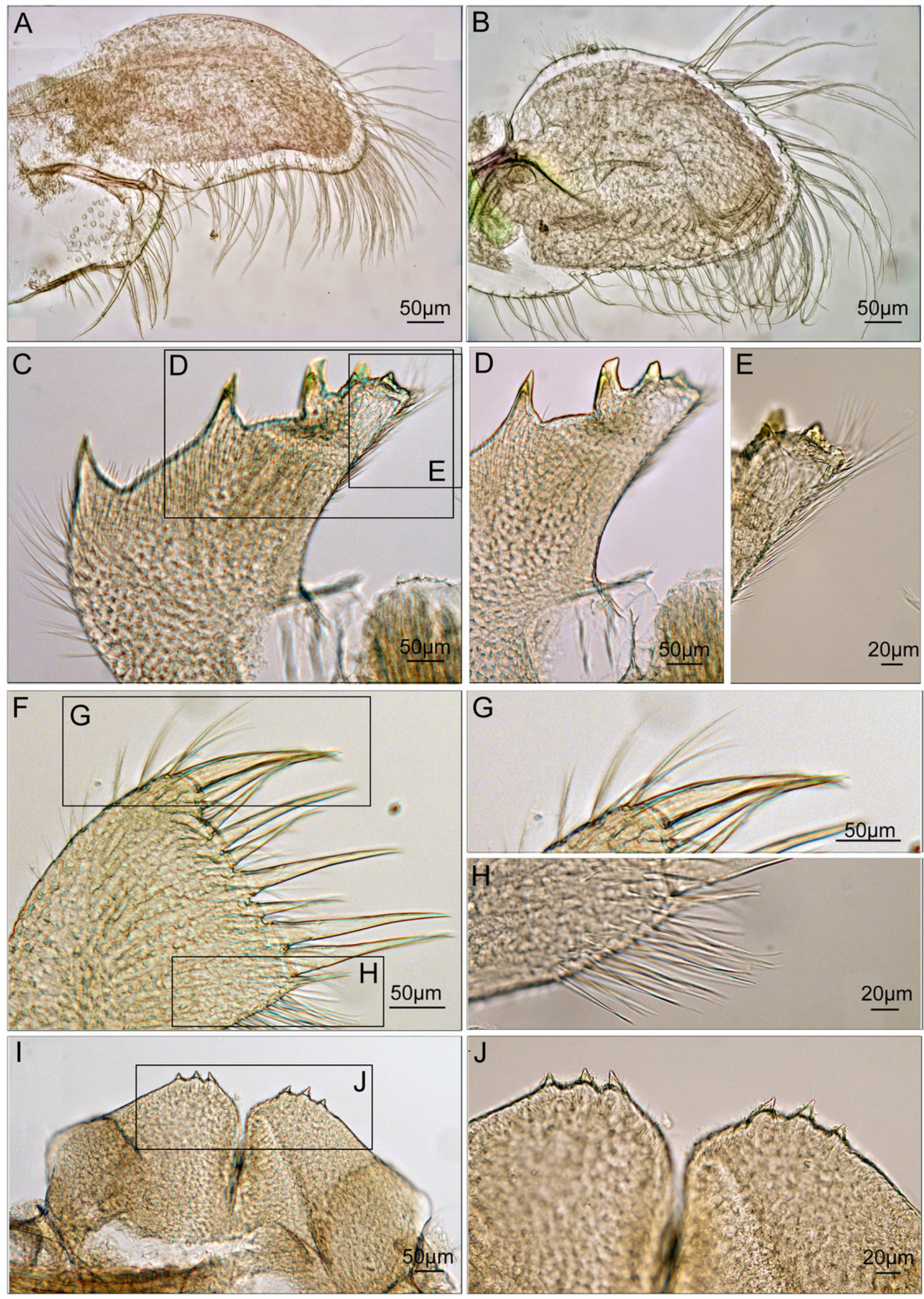


\section{Figure 8}

Figure 8 Scanning electron micrographs and revised drawings from previous published Illustrations.

(A) Cantellius euspinulosum; (B-D) Cantellius cf. euspinulosum 1-3; (E) Cantellius alveoporae

sp. nov.

A Cantellius euspinulosum
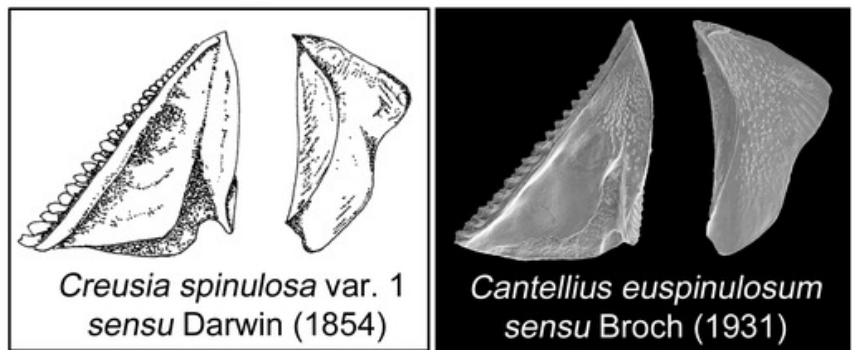

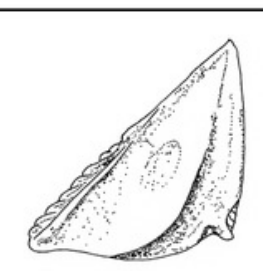

Cantellius euspinulosum sensu Nilsson-Cantell (1938)
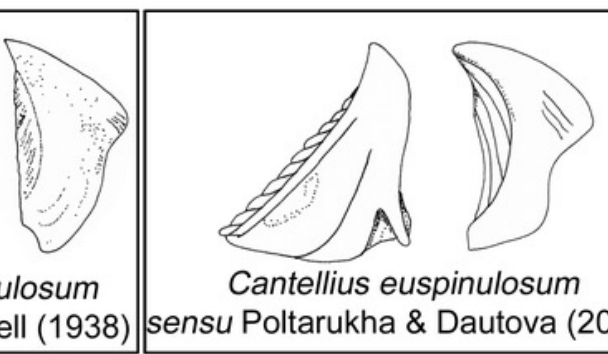

Cantellius euspinulosum sensu Poltarukha \& Dautova (2018)
B Cantellius cf.euspinulosum 1

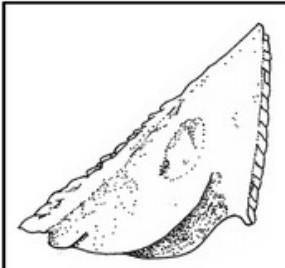

Cantellius euspinulosum seusu Nilsson-Cantell (1938)
C Cantellius cf.euspinulosum 2

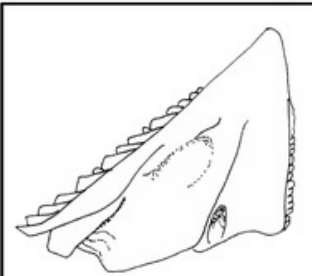

Cantellius euspinulosum sensu Anderson (1992)
D Cantellius cf.euspinulosum 3
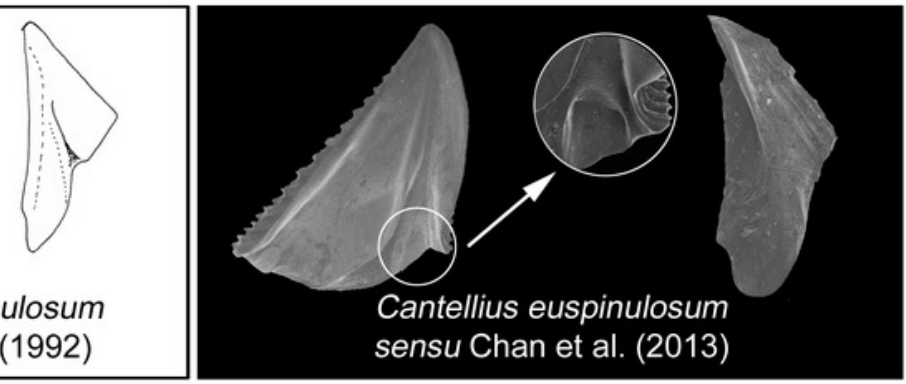
sensu Chan et al. (2013)

E Cantellius alveoporae sp. nov.

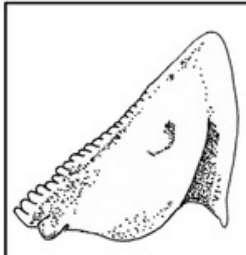

Cantellius euspinulosum sensu Hiro (1937)
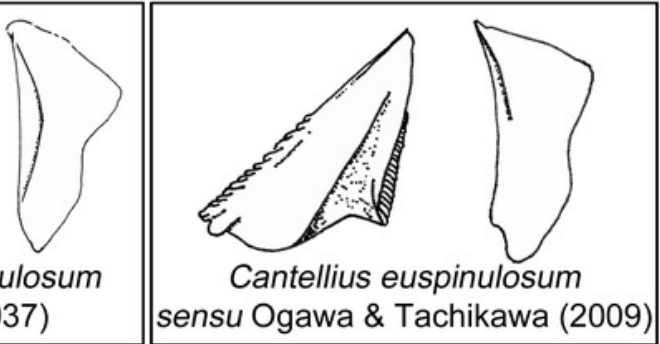
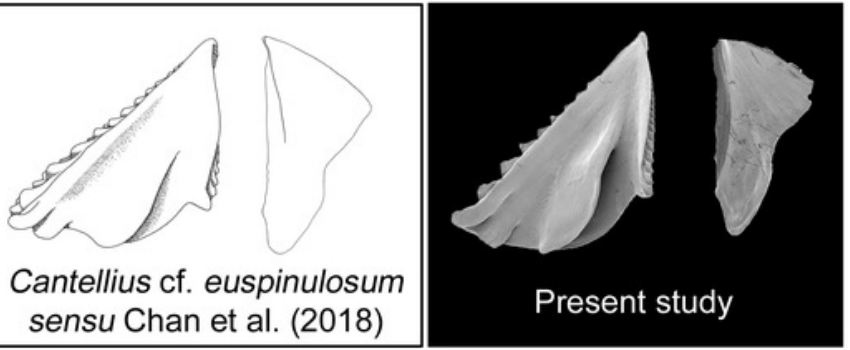
Figure 9

Figure 9 Global distribution of Cantellius species, with a total of 19 species reported including three species in Korea.

Global distribution of Cantellius species

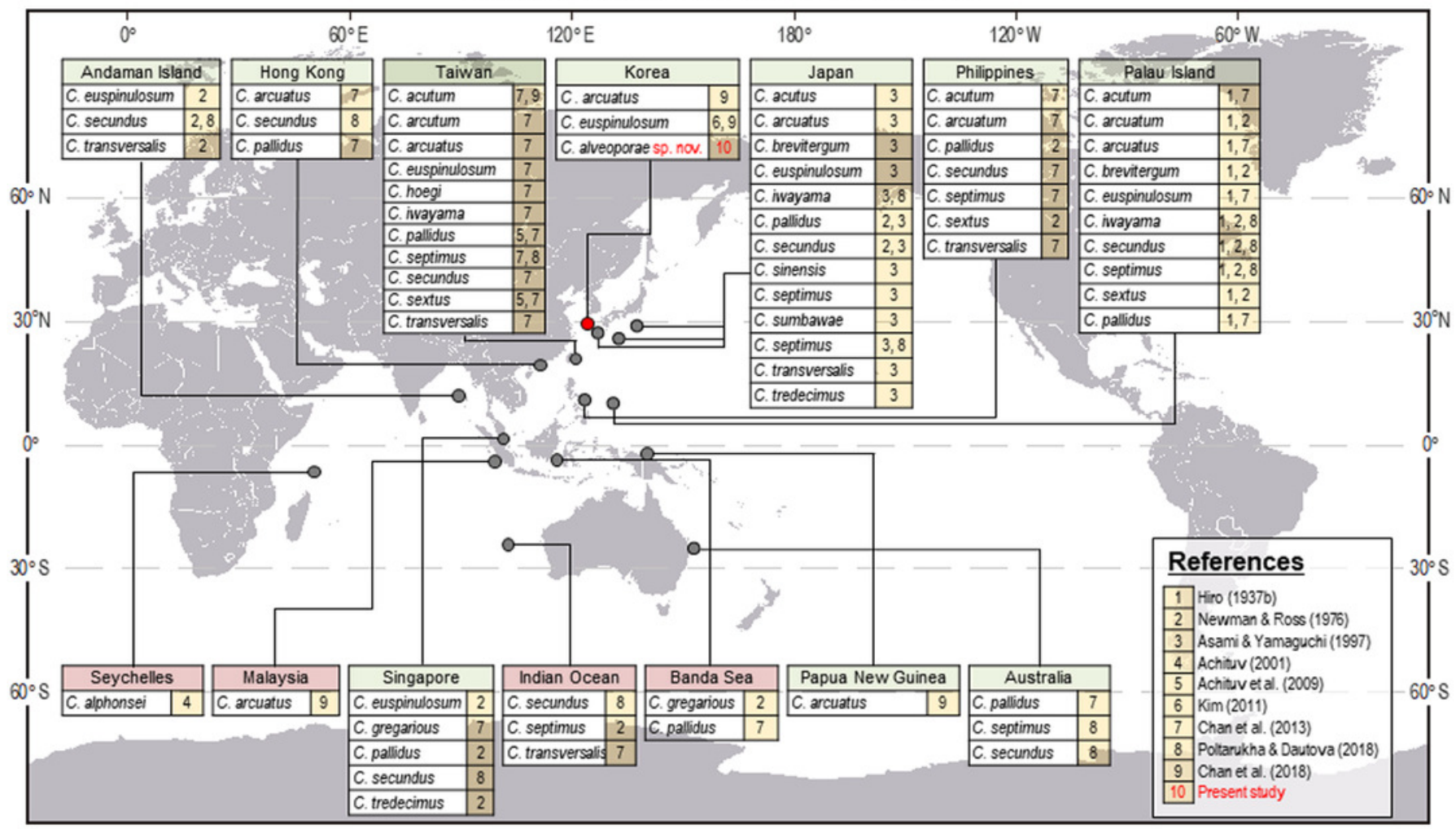

